\title{
EHMTI-0086. Pure mestrual vestibular migraine
}

\author{
C Mostardini i* G Nola ${ }^{2}$, R Giovanni ${ }^{3}$ \\ From 4th European Headache and Migraine Trust International Congress: EHMTIC 2014 \\ Copenhagen, Denmark. 18-21 September 2014
}

We describe two cases of a young patients affected, by benign paroxysmal positional vertigo (BPPV) during menstruation.

Patient 1, of 32, present BPPV every month with menstruation, associated with constrictive non pulsating mild headache. Patient 2, of 43, present BPPV 6/7 time/year always during menstruation associated with severe throbbing headache.

Both patients present history of kinetosis, familiarity for migraine, absence of vertigo and headache out of menstruation or during pregnancy.

For a lot of years they were followed by otolaryngology for BPPV and treated with canalith repositioning procedure, without results. Instrumental examination like brain MRI and audiometric tests were normal, only nystagmus was present every crisis.

Occurrence of the vertigo/headache and neurovegetative symptoms only during menstruation, we conclude for the diagnosis of Vestibular Migraine (VM) and treated like a pure menstrual migraine. Patient 1 undergone to a short term prophylactic therapy with naproxene $550 \mathrm{mg}$ bid starting before the period until the fourth day and frovatriptan 2,5 $\mathrm{mg}$ like rescue therapy, patients 2 for the unpredictability of the crisis should start with rizatriptan or naproxene followed by short term prophylactic like patient 1 . Both patients respectively after 4 and 6 month of observation, are free from headache and vertigo.

This case represent the important overlap between migraine and vertigo defined VM by International Headache Society. This overlap and its treatment is usually well recognized when headache is the prevalent symptom but is important improve collaboration between headache expert and otolaryngology, to always recognize a VM and treat it in the correct way.

No conflict of interest.

${ }^{1}$ Neurology Department, Giovan Battista Grassi Hospital, Roma, Italy

Full list of author information is available at the end of the article
Authors' details

${ }^{1}$ Neurology Department, Giovan Battista Grassi Hospital, Roma, Italy.

2Otolaringology Department, Giovan Battista Grassi Hospital, Roma, Italy.

${ }^{3}$ Sapienza, University of Rome Dept of Otolaryngology, Italy.

Published: 18 September 2014

doi:10.1186/1129-2377-15-S1-D43

Cite this article as: Mostardini et al:: EHMTI-0086. Pure mestrual vestibular migraine. The Journal of Headache and Pain 2014 15(Suppl 1):D43.

\section{SpringerOpen ${ }^{\circ}$}

(c) 2014 Mostardini et al; licensee Springer. This is an Open Access article distributed under the terms of the Creative Commons Attribution License (http://creativecommons.org/licenses/by/2.0), which permits unrestricted use, distribution, and reproduction in any medium, provided the original work is properly cited.
Submit your manuscript to a SpringerOpen ${ }^{\circ}$ journal and benefit from:

- Convenient online submission

- Rigorous peer review

- Immediate publication on acceptance

- Open access: articles freely available online

- High visibility within the field

- Retaining the copyright to your article

Submit your next manuscript at $>$ springeropen.com 